\title{
CHANGE OF HYDROGEN-HYDROCHEMICAL CONDITIONS OF AZOV SEA TAGANROG GULF AND THEIR INFLUENCE ON MICROZOPLANKTON IN WINTER PERIOD ${ }^{1}$
}

\author{
(C) Katerina V. Kreneva, Tatyana B. Filatova, \\ Alexey V. Kleschenkov, Anna M. Korshun
}

\author{
Federal research center southern scientific center of the Russian Academy of Sciences. \\ Rostov-on-Don, Russian Federation \\ North Caucasian branch of the Moscow technical university of communications and IT \\ Rostov-on-Don, Russian Federation \\ fila5784@mail.ru
}

An attempt is made to generalize the hydrochemical and hydrobiological results, obtained by the Southern Scientific Center of RAS and the Institute of Arid Zones of the SSC RAS in the study of the Taganrog Gulf waters in the winter of 2006-2017, and the distribution of hydrochemical components in snow, ice and under-ice water, the long-term changes in the salinity of the Taganrog Gulf are traced in detail according to two points of the observation, which is of theoretical and practical importance in predicting the hydrochemical regime, possible structural changes in the hydrobiocenosis and water quality of the water bodies. The stations most widely provided with data on the content of nutrients (nitrites, nitrates, ammonium nitrogen, dissolved nitrogen, nitrogen, phosphate, dissolved phosphorus, phosphorus, silicic acid) were compared. It is concluded that an increase in the salinity of the Azov Sea waters causes a steady trend of a decrease in the level of qualitative and quantitative characteristics of the Taganrog Gulf microzooplankton community, changes are observed in the dominant complex of ciliatocenosis species. The decrease in the species richness of microzooplankton is mainly due to freshwater and marine species. This process is probably associated with a negative effect of salinity on the primary production of organic matter and is part of a cycle of long-period fluctuations in salinity of the Azov Sea.

Key words: Taganrog Gulf, salinity, winter season, hydrochemical regime, monitoring of ciliatoplankton, biodiversity, quantitative characteristics of ciliatocenosis.

[К.В. Кренева, Т.Б. Филатова, А.В. Клещенков, А.М. Коршун Изменение гидрологогидрохимических условий Таганрогского залива Азовского моря и их влияние на микрозоопланктон в зимний период]

Сделана попытка обобщения гидрохимических и гидробиологических результатов, полученных Южным научным центром РАН и Институтом аридных зон ЮНЦ РАН при исследовании вод Таганрогского залива в зимний период 2006-2017 гг., изучено распределения гидрохимических компонентов в снегу, во льду и подледной воде, по двум пунктам наблюдений детально прослежены долговременные изменения солености Таганрогского залива, что имеет теоретическое и практическое значение при прогнозировании гидрохимического режима, возможных структурных изменений в гидробиоценозах и качества воды водных объектов. Сравнивались станции, наиболее широко обеспеченные данными по содержанию биогенных элементов (нитриты, нитраты, аммонийный азот, азот растворенный, азот валовый, фосфаты, фоссрор растворенный, фоосфор валовый, кремнекислота). Сделан вывод о том, что повышение солености вод Азовского моря вызывает устойчивый тренд понижения уровня качественных и количественных характеристик микрозоопланктонного сообщества Таганрогского залива, наблюдаются изменения в доминирующем ком-

${ }^{1}$ The publication is prepared in the part of the analysis of abiotic factors in the framework of the implementation of the GZ SSC RAS for 2018, No. gr. project 01201363187 , regarding the study of microzooplankton within the framework of the implementation of the PFI Presidium of RAS I.52 "Ensuring the sustainable development of the South of Russia in conditions of climatic, ecological and technogenic challenges" (GZ SSC RAS for 2018, No. gr. project AAAA-A18-118011990324-5)". 
плексе видов цилиатоценоза. Снижение видового богатства микрозоопланктона происходит, в основном, за счет пресноводных и морских видов. Данный процесс, вероятно, связан с отрицательным воздействием солености на первичную продукцию органического вещества и является частью цикла долгопериодных колебаний солености Азовского моря.

Ключевые слова: Таганрогский залив, соленость, зимний период, гидрохимический режим, мониторинг цилиатопланктона, биоразнообразие, количественные характеристики цилиатоценоза.

Katerina V. Kreneva - candidate of biological studies. Federal Research Center of the Southern Scientific Center of the Russian Academy of Sciences. Rostov-on-Don, Russia. Federation.

Tatyana B. Filatova - scientific worker. Southern scientific center of Russian Academy of Science. Rostovon-Don, Russian Federation.

Alexey V. Kleschenkov - candidate of geology, head of the department. Southern scientific center of Russian Academy of Science. Rostov-on-Don, Russian Federation.

Anna M. Korshun - candidate of geographical studies, assistant professor. North Caucasian branch of the Moscow technical university of communications and Informatics. Rostov-on-Don, Russian Federation.

Кренева Катерина Валерьевна - кандидат биологических наук, инженер-исследователь. Федеральный исследовательский центр Южный научный центр Российской академии наук. Ростовна-Дону, Россия.

Филатова Татьяна Борисовна - научный сотрудник. Южный научный центр Российской академии наук. Ростов-на-Дону, Россия.

Клещенков Алексей Владимирович - кандидат геологических наук, заведующий отделом. Южный научный центр Российской академии наук. Ростов-на-Дону, Россия.

Коршун Анна Михайловна - кандидат географических наук, доцент. Северо-Кавказский филиал Московского технического университета связи и информатики. Ростов-на-Дону, Россия.

The authors express their gratitude and appreciation to the staff of the Southern Scientific Center of Russian Academy of Sciences E.G. Aleshina, M.S. Milutka and K.S. Grigorenko, for assistance in carrying out the field and research works

The last decade is characterized by a low flowing of the Don in the result of which along with a number of other negative consequences the significant reconstruction of natural systems functioning of the Taganrog Gulf, esturial seashore and Don delta occurs. This is mainly conditioned by the Taganrog Gulf salinity increase, occurring in the consequence of the Don liquid effluent decrease. In this connection, the goal of this work was to describe the changes in the hydro-hydrochemical conditions of the Taganrog Gulf in winter under conditions of low water availability and the assessment of the microzooplankton community response to such changes.

The winter season represents the least studied period of ecosystem development of Azov sea and the Taganrog Gulf. Notwithstanding that the Azov sea is relatively wellstudied, the information about ecosystem functioning in the winter period is rather poor [2]. The available data on the state of the Azov sea pelagial cover observations, made in conditions of mild winters with a relatively weak ice cover [14]. At the same time, the winter period is one of the most important seasons for understanding the patterns of functioning and formation of the ecosystem productivity of the Taganrog Gulf and the Azov sea.

The Southern Scientific Center of the RAS has been conducting winter researches for more than 15 years on the diesel icebreaker "Captain Demidov" and SRS "Professor Panov" during the annual winter monitoring of the main parameters of the environment and biota in the coastal zone of the Taganrog Gulf. The result of this work was the replenishment of the unique database of the Azov sea for the main abiotic and biotic indi- 
cators, detailed analysis and interpretation of the materials are set out in publications [3, 8, 9].

Current climatic changes are reflected at all levels of organization of terrestrial and marine ecosystems. The Taganrog Gulf was chosen as an object of research, which occupies a special place in the ecosystem of the Azov sea as an estuary reservoir, the most important features of which are small depths and the formation of a zone of river and sea waters, mixing within its boundaries. Besides, it is the most ice-infested region of the Azov sea, which is explained by extremely favorable conditions for ice formation: the position of the gulf between the isotherms of January -5 and $-6^{\circ} \mathrm{C}$ (the coldest part of the sea), the flow into the Gulf of the Don river and the shallow waters of the Gulf. This region is also characterized by the greatest significant load of biogenic runoff and a pronounced horizontal gradient of salinity [2].

Sampling of microzooplankton, hydrochemical samples and carrying out of researches of thermohaline characteristics of water were carried out from the icebreaker "Captain Demidov" in late February-early March from 2003 to 2017, and also during onshore observations of the Taganrog Gulf from 2012 to 2017 on the network of stations, located at the southern coast of the Taganrog Gulf (Port-Caton, Chumbur-Spit, PavloOchakovo Spit) and at the northern (Beglitskaya Spit, Petrushino, Mikhailovka). Subglacial water samples were selected, where the following parameters were determined: nitrites, nitrates, ammonia nitrogen, dissoluted nitrogen, gross nitrogen, phosphates, dissoluted phosphorus, gross phosphorus, the dissolved load, suspended substances content, ionic composition.

A plastic bucket and a Molchanov bathometer were used for the sampling of water. Immediately at the station, the air temperature, the water temperature, the concentration of dissolved oxygen were measured. Water samples were taken into polyethylene bottles and transported in a cold bag.

After the samples filtering, the concentrations of the dissolved nutrients were determined using standard techniques, recommended for use in ocean hydrochemical studies: phosphates - by the method of Morphy and Riley [13]; nitrite - by the method of Bandschneider and Robinson [10]; nitrates - according to the method of Morris and Riley (in the modification of Grasshoff, Strickland and Parsons, Sapozhnikov, Gusarova, Lukashev) [10]; ammonium ions - by the method of Sagee-Solorzano [12]. The concentration of oxygen dissolved in water was determined by the Winkler method [10]. When analyzing water samples, the photometer "Expert-003" was used. The $\mathrm{pH}$ values and the water temperature were determined using a HANNA pH meter. Thermohaline characteristics of water were measured by the oceanographic probe CTD-90 (SeaSun Tecnology Gmbh).

Collection of plankton samples was carried out by standard methods. Part of the samples was fixed with an acidic Utermel solution for processing in a stationary laboratory of the Institute. Their concentration was carried out by a sedative method. Part of the samples was examined live on board immediately after sampling or in the laboratory within 24 hours after sampling. The quantitative registration of the infusorians was carried out by a modified method of N.S. Gaevskaya (1949) [1]. Information on the content of nutrients in the subglacial water and numerical characteristics of microzooplankton was processed by mathematical statistics using the data analysis program EXCEL.

Long-term changes in the salinity of the Taganrog Bay were traced in detail by two observation points, in the area of the Pavlo-Ochakovo spit $(11 \mathrm{~km}$ from the mouth of the Don) and the Sazalnitskaya spit (60 km from the mouth of the Don), for which the dynamics of salinity growth for 16 years, from 2001 to 2017 was determined. Periodic fluctuations in salinity are associated with intra-annual fluctuations in the costs of the Don in the phases of floods, the intermittent periods, the associated with them releases of the Tsimlyanskaya HES, and the overtaking phenomena. Despite such fluctuations, 
there is a noticeable positive trend in salinity at both observation stations. Until the February 2005 salinity values within the range 4-4,4\%o were observed at the station Sazalnitskaya spit, in May 2015 there was a jump to11\%o. The Pavlo-Ochakovo spit is in the immediate proximity from the Don delta, therefore the changes in the thermohaline structure of the Azov sea are manifested later and are not so expressed. From 2002 to 2013 Salinity fluctuated within 0.8-1.3 \%o, with short bursts up to 3-4 \%o. In 2016, salinity minima increased on average to 4-5\%. Against the background of the general trend towards the salinity of the Taganrog Gulf in winter, there are certain differences in the distribution of temperature and salinity from year to year. So in winter 2013, a water temperature of $0.16^{\circ} \mathrm{C}$ was observed at the Pavlo-Ochakovo spit and a salinity of $3.84 \%$ was recorded, which naturally decreased with the movement towards the north. Kagalnik up to $0.05^{\circ} \mathrm{C}$ and salinity $0,6 \%$, minimum salinity in winter for 2013-2017 on the Pavlovo-Ochakovo spit was $0.8 \%$ in 2014 (table 1).

The range of salinity change at the easternmost point of coastal observations on the southern coast (Port-Caton) was from 3.2 to $8.1 \%$, at the easternmost station of the northern coast (Beglitskaya spit) from $3.2 \%$ to $6.3 \%$ respectively.

Such significant changes are caused, on the one hand, by the factor of the river flow volume, the minimum of which occurred in January $2016\left(326 \mathrm{~m}^{3} / \mathrm{sec}\right.$ at the closing post in the Razdorskaya station), and the maximum for the period studied in January $2017\left(540 \mathrm{~m}^{3} / \mathrm{s}\right)$. Another factor that determines the presence of a lateral salinity gradient is that Taganrog Gulf is the most ice-infested region of the Azov sea, and very often it is covered with ice, while the rest of the sea is ice-free and wind currents form within it. The trajectory of fresh water, flowing with the drain of the Don River, depends on the prevailing wind direction and, as a consequence, on the direction of circulation of currents in the bay, complicated by the conditions of ice formation. In the conditions of the eastern wind, the fresh water stream is directed along the southern coast, at the same longitude on the northern coast salinity can be almost twice as high, with the winds of the western components the most fresh runoff is distributed in the eastern part of the bay with a small river bend along the northern shore (table 1). This finds a regular reflection in the hydrochemical characteristics of water.

In February 2014, the nitrite content in the sub-surface water varied from 10.0 to $20.0 \mu \mathrm{g} / \mathrm{I}$, nitrates from 143.0 to $483.0 \mu \mathrm{g} / \mathrm{I}$, phosphates from 12.0 to $47.0 \mu \mathrm{g} / \mathrm{I}$. The thickness of ice in February 2015 was significant $(4.8-5.5 \mathrm{~cm})$ in comparison with February $2007(0.5-1 \mathrm{~cm})$. According to the daily average temperatures of water and air and the duration of the ice formation, the winter of 2015 (the beginning of the year) is attributed to cold winters. In February 2015, the content of nitrite in the sub-ice water varied from 4.0 (Petrushino station) to $24.0 \mu \mathrm{g} / \mathrm{I}$, nitrates from 1110.0 (Mikhailovka station) to $3,090.0 \mu \mathrm{g} / \mathrm{I}$, phosphates - from 3.0 (Petrushino station) to $77.0 \mu \mathrm{g} / \mathrm{I}$. The concentrations of nutrients were minimal at stations near the northern coast of the Taganrog Gulf and are maximum at the southern stations of the Pavlo-Ochakovo spit and Chumbur-spit. In February 2016, the content of nutrients in the subglacial water changed in the following intervals: ammonium ions from 60 to $140.0 \mu \mathrm{g} / \mathrm{I}$, nitrites from 15.0 to 24.0 $\mu \mathrm{g} / \mathrm{I}$, nitrates from 290.0 to $1120.0 \mu \mathrm{g} / \mathrm{I}$, gross nitrogen from 910.0 to $2310.0 \mu \mathrm{g} / \mathrm{I}$, phosphates from 5.0 to $54.0 \mu \mathrm{g} / \mathrm{I}$, gross phosphorus from 98.0 to $221.0 \mu \mathrm{g} / \mathrm{I}$, silicon from 2100.0 to $7000.0 \mu \mathrm{g} / \mathrm{I}$ [15]. 
Table 1. Summary of the temperature and salinity of water in the coastal zone of the Taganrog Gulf according to observation data 2013-2017

\begin{tabular}{|c|c|c|c|c|c|c|c|c|c|c|c|c|c|c|c|c|c|c|c|c|}
\hline & \multicolumn{4}{|c|}{$29-31.01 .2013$} & \multicolumn{4}{|c|}{$12-13.02 .2014$} & \multicolumn{4}{|c|}{ 19-20.02.2015 } & \multicolumn{4}{|c|}{$11-12.02 .2016$} & \multicolumn{4}{|c|}{ 20-21.02.2017 } \\
\hline Station & 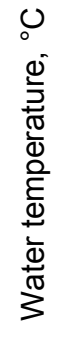 & 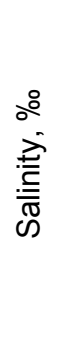 & 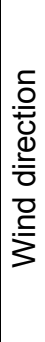 & 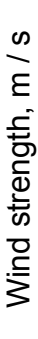 & 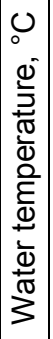 & 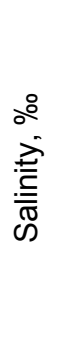 & 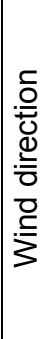 & 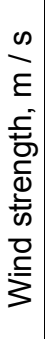 & 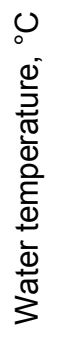 & 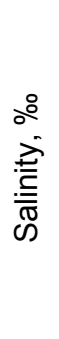 & 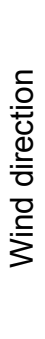 & 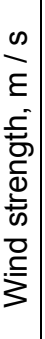 & 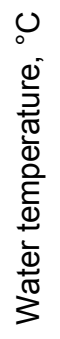 & 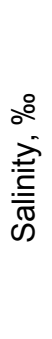 & 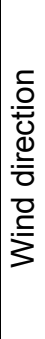 & 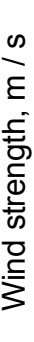 & 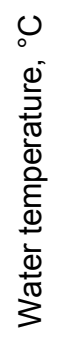 & 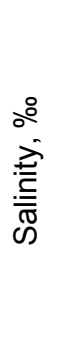 & 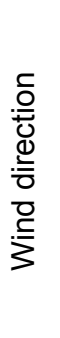 & 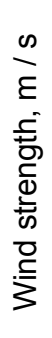 \\
\hline $\begin{array}{c}\text { Beglitskaya } \\
\text { spit }\end{array}$ & & & & & & & & & 0,2 & 6,3 & ш & 2 & 0,1 & 5,8 & $\begin{array}{l}3 \\
\text { S. } \\
3 \\
3\end{array}$ & 1 & 0,1 & 3,2 & 오 & 1 \\
\hline Petrushino & & & & & & & & & 1,0 & 2,7 & ш & 2 & 0,7 & 2,6 & 定 & 1 & 1,4 & 1,1 & 오 & 1 \\
\hline Mikhailovka & & & & & & & & & 1,4 & 1,7 & ш & 2 & & & 定 & 1 & 0,2 & 0,9 & 오 & 1 \\
\hline $\begin{array}{c}\text { Pavlo- } \\
\text { Ochakovska } \\
\text { ya spit }\end{array}$ & 0,2 & 3,8 & 岕 & 1 & 1 & 0,8 & $\begin{array}{l}3 \\
\text { S1 } \\
3\end{array}$ & 1 & 0,0 & 1 & $\frac{3}{6}$ & 5 & $-0,1$ & 4,3 & ш & 6 & 1,3 & 0,9 & 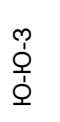 & 8 \\
\hline $\begin{array}{c}\text { Chumbur } \\
\text { spit }\end{array}$ & & & & & & & & & 1,0 & 2,5 & क & 5 & 1,3 & 7,6 & ш & 6 & 0,3 & 2,2 & 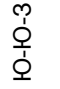 & 8 \\
\hline Port-Caton & & & & & 0,8 & 4,7 & $\begin{array}{l}3 \\
\text { के } \\
3\end{array}$ & 1 & 0,3 & 3,2 & क & 5 & 1,6 & 8,1 & ш & 6 & 0,6 & 4,4 & 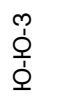 & 8 \\
\hline Kagalnik & 0,1 & 0,6 & $\ddot{\omega}$ & 1 & 0,4 & 0,6 & D & 1 & & & & & & & & & & & & \\
\hline Zaimoobryv & 0,1 & 1,3 & 0 & 0 & & & & & & & & & & & & & & & & \\
\hline
\end{tabular}

Monitoring of the ciliatocenosis of the Taganrog Gulf showed that there is a stable trend (2012-2017) of a decrease in the level of qualitative and quantitative characteristics and a restructuring of the planktonic infusorians community structure in winter. In winter, the community of microzooplankton is formed mainly from species belonging to the "shallow" size group. In the absence of ice or the emergence of dilutions, the proportion of "large" and "medium" size groups of infusorians increases. In 2003, the dominant species in the Taganrog Gulf area were Rhabdostyla sp., Tintinnopsis minuta (Wailes, 1925 ) or small strombidiums. On the whole investigated water area there was a comparatively large predator Didinium nasutum (O.F. Muller, 1876). In 2006, the marine species of Tintinnopsis beroidea (Stein, 1867) and Strobilidium sp. prevailed. In addition, Euplotes balteatus was met in a significant number (Dujardin, 1841). In 
2012-2014 years small and medium representatives of the Strombidium kind dominated (Claparède \& Lachmann, 1859). Throughout our the research from 2003 to 2014, in winter period, 3-4 species of the Codonellidae family were regularly observed in the Taganrog Gulf area (Kent, 1881). In 2016-2017 years the dominant species in the Taganrog Gulf area were Halteria grandinella (Müller, 1773) and small strombidiums. Representatives of the family Codonellidae were completely absent.

Most of the infusorians that occur in the Taganrog Gulf in winter are euryhaline species that occur throughout the sea area. Considering the seasonal aspect, we can say that a low temperature regime is not a decisive factor for the infusorians development. The presence of food allows the ciliates to develop successfully even under subsurface conditions. The number of ciliates in February 2016 ranged from 0.1 to 1.0 million ex./m3, an average of 0.6 million ex./m3. The biomass averaged $18.5 \mathrm{mg} / \mathrm{m} 3$. The number of infusorians in February-March 2017 varied from 0.1 to 1.4 million ex./m3, an average was 0.5 million ex./m3. The biomass averaged $16.2 \mathrm{mg} / \mathrm{m} 3$. The observed decrease is more pronounced than in 2014, when the level of qualitative and quantitative characteristics development of microzooplankton was 2-12 times lower than in previous years (Table 2).

Table 2. Dynamics of qualitative and quantitative characteristics community of microzooplankton in the winter 2003-2017

\begin{tabular}{|c|c|c|c|c|c|c|c|c|}
\hline \multicolumn{2}{|c|}{ January February } & 2003 & 2006 & 2008 & 2012 & 2014 & 2016 & 2017 \\
\hline$\frac{\pi}{\frac{\pi}{\partial}}$ & $\begin{array}{c}\text { average, } \\
\text { million ex. } / \mathrm{m}^{3}\end{array}$ & 0.9 & 4.2 & 11.9 & 2.3 & 1,0 & 0,6 & 0,5 \\
\hline$\stackrel{\vec{Z}}{\underline{Z}}$ & $\begin{array}{c}\text { number of } \\
\text { species }\end{array}$ & 19 & 24 & 21 & 16 & 14 & 10 & 7 \\
\hline
\end{tabular}

Comparing the data, obtained with previous studies $[4-8,16]$, we can say that in 2016-2017 the level of quantitative and qualitative characteristics development is lower than in previous years of observation. Comparable in terms of the level of our data were observed only in 2003, after an abnormally cold winter. Both biodiversity and the number of infusorians in 2003 were slightly higher.

The decrease in the species richness and abundance of microzooplankton was due to freshwater species (for example, the representatives of the r. Strobilidium (Schewiakoff, 1892) and marine species (family Codonellidae), which agrees with the minimum law of the Remane species (1934) in the critical salinity zone. In combination with the pronounced tendency to increase the salinity of the Azov sea and the Taganrog Gulf waters (Figure 1), this allows us to speak of the decisive significance of the salinity factor in the observed decrease in the density of microzooplankton. 


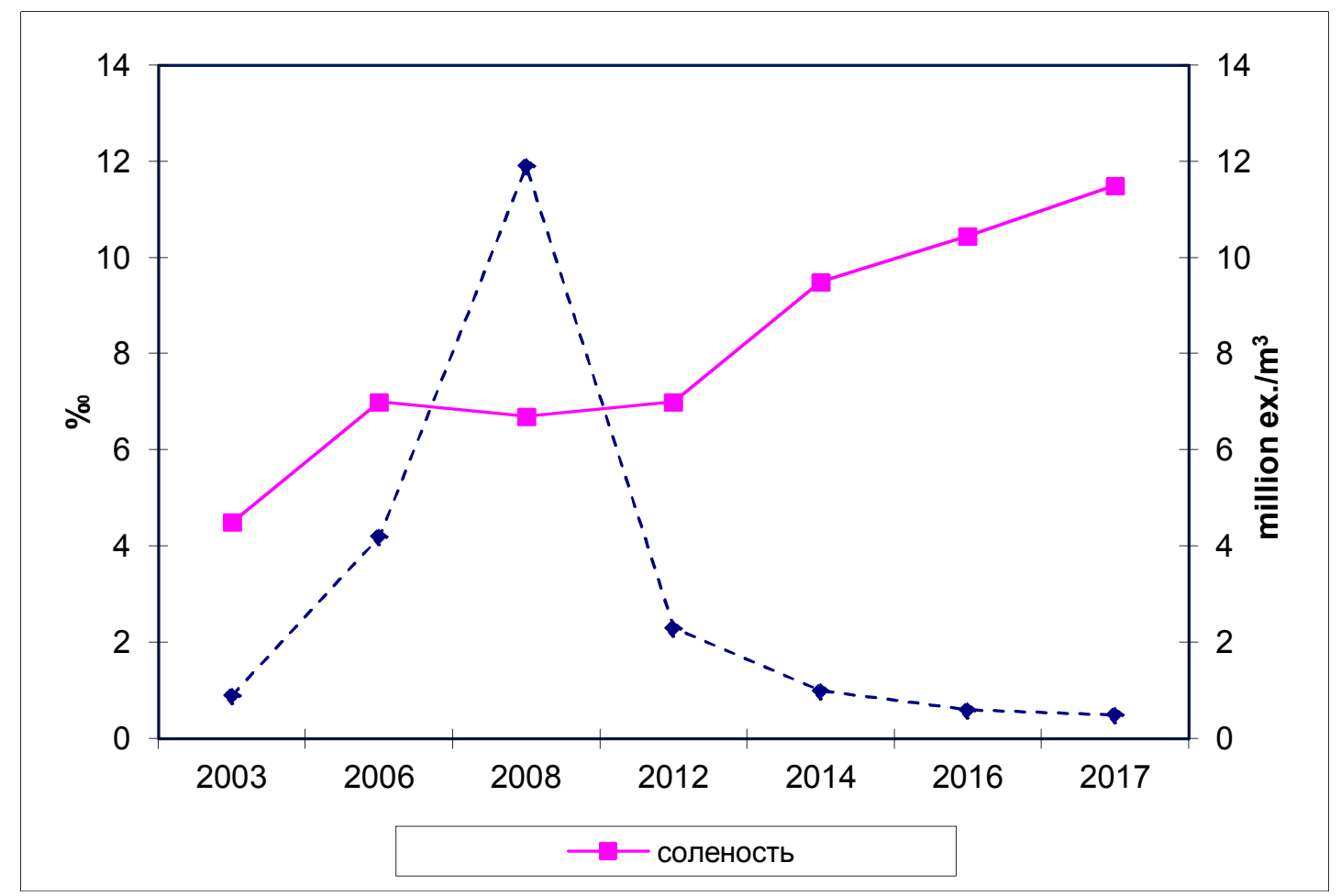

Figure 1. Dynamics of changes in salinity and density of infusorians in the period from 2003 to 2017

The value of this factor is confirmed by the literature data. Unfortunately, until 1995 the data on the microzooplankton of the Azov sea have a fragmentary character. However, there are data on biomass and the number of infusoria species found in the water area from 1937 to 1949 in the work [11]. This period, as well as the modern one, is characterized by a pronounced trend towards an increase in salinity. Salinity of the Azov Sea increased from $9 \%$ in 1934 to $12 \%$ in 1952. Also this period is characterized by the lowest, according to available data, quantitative characteristics of the community of ciliatoplankton. The average biomass of infusorians in the period 1937-1949 was $16.5 \mathrm{mg} / \mathrm{m}^{3}$. The number of species found in the water area corresponds to the level of $2014-14$ species. Based on the foregoing, it can be concluded that an increase in the salinity of the Azov sea waters provides a steady trend of lowering the level of qualitative and quantitative characteristics of the Taganrog Gulf microzooplankton community. Changes are observed in the ciliatocenosis species dominant complex. The decline in the species richness of microzooplankton is mainly due to freshwater and marine species. In addition, this process is probably associated with a negative effect of salinity on the primary production of organic matter [8] and is part of a cycle of long-period fluctuations in salinity of the Azov sea.

\section{Лumepamypa}

1. Гаевская Н.С. Простейшие (Protozoa) // Жизнь пресных вод СССР. М.Л.: АН CCCP. 1949. T.2.

2. Гидрометеорология и гидрохимия морей СССР. Азовское море. Т.5. / Ред. Терзиев Ф.С. СПб., 1991.

3. Комплексные экосистемные исследования Азовского моря в зимний период (2003-2006 гг.). Ледокольные экспедиции и береговые наблюдения / Г.Г. Матишов, Д.Г. Матишов, О.В. Степаньян и др. Ростов-н/Д, 2006. 
4. Кренева К.В. Экология массовых видов планктонных инфузорий Азовского моря. Автореф. дисс....канд. биол.н. Мурманск, 2006.

5. Кренева К.В. Характеристика сообщества микрозоопланктона Азовского моря в зимний период // Комплексный мониторинг среды и биоты Азовского бассейна. Том VI. Апатиты, 2004.

6. Матишов Г.Г., Абраменко М.И., Гаргопа Ю.М., Буфетова М.В. Новейшие экологические френомены в Азовском море (вторая половина XX века). Апатиты, 2003. Т. 5.

7. Матишов Г.Г., Матишов Д.Г., Степаньян О.В., Лебедева Н.В., Инжебейкин Ю.И., Поважный В.В., Кренева К.В., Ковалева Г.В., Сойер В.Г., Савицкий Р.М., Калинкин Б.Д., Липкович А.Д. Комплексные экосистемные исследования Азовского моря в зимний период (2003-2006 гг.). Ледокольные экспедиции и береговые наблюдения. Ростов-н/Д, 2006.

8. Матишов Г.Г., Степаньян О.В., Поважный В.В., Ковалёва Г.В., Кренёва К.В. Функционирование экосистемы Азовского моря в зимний период (по результатам ледокольных экспедиций 2003-2006 гг.) ДАН, 2007. Т. 413. №1.

9. Матишов Г.Г., Степаньян О.В., Ковалева Г.В. Особенности структуры пелагического сообщества Азовского моря в условиях аномально холодной зимы 2005-2006 гг. // Вестник ЮНЦ. 2012. № 4.

10. Методы гидрохимических исследований основных биогенных элементов.Москва, 1988.

11. Пицык Г.К., Новожилова А.Н. О динамике зоопланктона Азовского моря. 1951. Вып. 15.

12. РД 52.24.383-2005. Массовая концентрация аммиака и ионов аммония в водах. Методика выполнения измерений фотометрическим методом в виде индофенолового синего. Ростов-на-Дону, 2005.

13. РД 52.24.382-2006. Массовая концентрация фосфратов и полифосфатов в водах. Методика выполнения измерений фотометрическим методом. Ростов-на-Дону, 2006.

14. Студеникина Е.И., Алдакимова А.Я., Губина Г.С. Фитопланктон Азовского моря в условиях антропогенных воздействий. Ростов-на-Дону, 1999.

15. Филатова Т.Б., Алёшина Е.Г., Клещенков А.В. Таганрогский залив зимой: распределение гидрохимических компонентов // Научный альманах стран Причерноморья. 2016. Т. 8. № 4. С. 47-51.

16. Шляхова Н.А. Исследование планктонных инфузорий как компонента экосистемы Азовского моря. Автореф. дисс....канд. биол. наук. Краснодар, 2000.

\section{References}

1. Gaevskaya N.S. Protozoa // Life of fresh USSR waters. M.L.: AS USSR.1949. V.2..

2. Hydrometeorology and hydrochemistry of the seas of the USSR. Azov sea. V. 5. $\mathrm{SPb}, 1991$.

3. Complex ecosystem research of the Azov sea in winter (2003-2006). Icebreaking expeditions and coastal observations / G.G. Matishov, D.G. Matishov, O.V. Stepanyan and others. Rostov-on-Don, 2006.

4. Kreneva K.V. Ecology of mass species of plankton infusorians of the Azov Sea. Abstract of thesis of candidate of biological studies. Murmansk, 2006.

5. Kreneva K.V. Characteristics of the microzooplankton community of the Azov Sea in winter // Complex monitoring of the environment and biota of the Azov basin. Vol. VI. Apatity, 2004. 
6. Matishov G.G., Abramenko M.I., Gargopa Yu.M., Bufetova M.V. The newest ecological phenomena in the Sea of Azov (second half of the 20th century). Apatity, 2003. V. 5.

7. Matishov G.G., Mam Matishov D.G., Stepanyan O.V., Lebedeva N.V., Inzhebeikin Yu. I., Povazhnyi V.V., Kreneva K.V., Kovaleva G.V., Soiyer V.G.., Savitskii R.M., Kalinkin B.D., Lipkovich A.D. Complex ecosystem research of the Azov Sea in winter (2003 - 2006). Icebreaking expeditions and coastal observations. Rostov-on-Don, 2006.

8. Matishov G.G., Stepanyan O.V., Povazhnyi V.V., Kovaleva G.V., Kreneva K.V. Functioning of the Azov sea ecosystem in winter period (by the results of icebreaking expeditions 2003-2006) / DAN, 2007. V. 413. No1.

9. Matishov G.G., Stepanyan O.V., Kovaleva G.V. Peculiarities of the Azov sea pelagic community structure in conditions of an abnormally cold winter 20052006 // Vestnik. SSC. 2012. No 4.

10. Methods of hydrochemical studies of basic biogenic elements. Moscow, 1988.

11. Pitsyk G.K., Novozhilova A.N. On the dynamics of the Azov Sea zooplankton. 1951. No 15.

12. DD 52.24.383-2005. 52.24.383-2005. Mass concentration of ammonia and ammonium ions in water. The procedure for performing measurements by the photometric method in the form of indophenol blue. Rostov-on-Don, 2005.

13. DD 52.24.382-2006. Mass concentration of phosphates and polyphosphates in water. Method of measurement by photometric method. Rostov-on-Don, 2006.

14. Studenikina E.I., Aldakimova A.Ya., Gubina G.S. Phytoplankton of the Azov sea under anthropogenic influences. Rostov-on-Don, 1999.

15. Filatova T.B., Aleshina E.G., Kleschenkov A.V. Taganrog Gulf in winter: distribution of hydrochemical components // Science Almanac of Black sea region countries. 2016. V. 8. № 4. p. 47-51.

16. Shlyakhova N.A. Investigation of planktonic infusorians as a component of the Azov sea ecosystem. Abstract of a thesis of candidate of biological studies. Krasnodar, 2000. 